\title{
How the Idea of Profession Changed the Writing of Medical History
}

\author{
by

\section{JOHN C. BURNHAM}

(Medical History, Supplement No. 18)

\author{
London
}

Wellcome Institute for the History of Medicine 1998 


\section{Contents}

List of illustrations $\quad$ ix

Acknowledgements $\quad$ xi

$\begin{array}{ll}\text { Introduction } & 1\end{array}$

Chapter 1. From the Beginnings of Medical History to the Turn of the Twentieth Century: Establishing a Tradition 11

Chapter 2. The Classic Configuration and the Advent of Social History in the Early Twentieth Century 36

Chapter 3. The Sociology and History of Professions:

A Path That Mid-Century Medical Historians Did Not Take 69

Chapter 4. The Incursion of Sociology and a New Intellectual Context: The Mid-Sixties to the Late Seventies

Chapter 5. Medical Historians Take Over the Concept:

The Late Twentieth Century 126

Chapter 6. Perspectives from the End of the Twentieth Century 158

Index 


\section{How the Idea of Profession Changed the Writing of Medical History}

(Medical History, Supplement No. 18) 
Copyright $($ C The Trustee, The Wellcome Trust, 1998. All Rights Reserved. No part of this publication may be reproduced, stored in a retrieval system, or transmitted, in any form or by any means, electronic, mechanical photocopying, recording or otherwise, without prior permission.

\section{ISBN 0854840672}

Supplements to Medical History may be obtained by post from Professional and Scientific Publications, BMA House, Tavistock Square, London WC1H 9JR. 


\section{Dedicated to}

Ynez Violé O'Neill

and other innovative and scholarly medical historians

in our times 